\title{
ПЕРЕБУДОВА ХІМІЧНОГО СКЛАДУ КІСТКОВОЇ ТКАНИНИ У ВІКОВОМУ АСПЕКТІ ЗА РІЗНИХ РЕЖИМІВ РУХОВОЇ АКТИВНОСТІ
}

\author{
๑Н. О. Давибіда, Н. М. Безпалова, Л. В. Новакова, А. В. Руцька
}

ДВНЗ «Тернопільський державний медичний університет імені І. Я. Горбачевського МОЗ України»

\begin{abstract}
РЕЗЮМЕ. Глибоке вивчення процесів перебудови кістковоїтканини, ї̈будови, хімічного складу, адаптаційних можливостей $\epsilon$ необхідною умовою виявлення закономірностей впливу праці, спорту та ряду професій, що виникають у зв'язку з науково-технічним прогресом, на організм. Моделювання різних режимів рухової активності не в повній мірі відповідає тренувальним процесам людини у фізичній культурі та спорті. Однак результати, отримані при даному експериментальному дослідженні, мають відношення до розкриття загальнобіологічних закономірностей, що грунтуються на індивідуальних і генетично обумовлених особливостях індивідуумів, знання котрих послужить морфологічним обґрунтуванням тренувального процесу і прогнозуванню структурних перетворень в скелеті при різних режимах рухової активності, запобіганню травм та розвитку остеопорозу.

КЛЮчОВІ СЛОВА: фізичні навантаження, витривалість, макро-мікроелементи, плечова кістка.
\end{abstract}

Вступ. Вплив фізичних навантажень на організм людини в цілому та структуру довгих трубчастих кісток зокрема вивчали багато авторів впродовж декількох десятиріч, але і на сьогодні $\epsilon$ актуальним у спортивній медицині, спорті, фізичній культурі.

Дослідження функціональної анатомії о6'єднують експериментально-морфологічні дослідження, які присвячені впливу умов життя, праці, спорту, фізичних навантажень на формування і будову всього організму та на окремі його органи. Кістка завжди була цікавим об'єктом дослідження і особливо активно вивчається протягом багатьох десятиріч $[1,3,4]$.

Але і на сьогодні дослідження кісток скелета не втратило своєї актуальності [2]. Змінюються умови життя людини, навколишнього середовища, харчування, з'являються новітні види спорту. Вплив останніх на організм часом потребує детального вивчення [6-8]. Всі ці зміни впливають на ріст і розвиток кісток, особливо в юному віці. Кісткова система $\epsilon$ складною та водночас лабільною у функціональному і морфологічному відношеннях. Вона реагує на різні внутрішні і зовнішні фактори. Поліфункціональність і визначає первинну складність у вивченні функціональної морфології опорно-рухового апарату. Незважаючи на те, що в сучасній літературі $\epsilon$ достатньо даних, присвячених впливу фізичних навантажень динамічного характеру на ріст і розвиток довгих кісток, повної ясності у цьому питанні немає.

Робота виконана в межах комплексної науково-дослідної теми Тернопільського державного медичного університету ім. І. Я. Горбачевського «Вторинний остеопороз: патогенетичні механізми формування та прогресування, клініко-інструментальні та біохімічні маркери ранньої діагностики, профілактики і лікування" № держреєстрації 0104U004523), частиною якої $\epsilon$ науково-дослідна робота кафедри анатомії людини «Вивчення коригуючих факторів на перебіг експериментального остеопорозу. Вплив зневоднення організму, різних режимів рухової активності на структуру довгих кісток та нирок і фізичного розвитку в залежності від впливу вегетативного статусу». У виконанні їі автором проведено дослідження росту та формоутворення кісток скелета при фізичних навантаженнях у віковому аспекті.

Матеріал і методи дослідження. Білі щури були вибрані нами як об'єкт для дослідження через їх порівняно невеликий життєвий цикл і безперервний ріст кісток скелета; це дозволяє впродовж короткого часу прослідкувати процеси остеогенезу. Для вирішення поставлених задач був проведений експеримент на 180 білих безпородних лабораторних щурах-самцях. Всі тварини були поділені на три групи віком 60-120 днів (молоді щури) вагою 120-180 г, 140-200 днів, вагою 200 - 250 г (зрілі щури) і 560-620 днів (старечі щури) вагою $300-400$ г. Вибір цих вікових груп був здійснений згідно з класифікацією В. М. Махінько і В. Н. Нікітіна (1977). Комплекс використаних методик дозволив у певній мірі висвітлити проблему впливу фізичних динамічних навантажень на ростові та функціональні особливості довгих кісток тварин у віковому аспекті. Оскільки кістка $\epsilon$ депо мінеральних речовин, проводили дослідження хімічного складу кісток. Вміст води у кістках визначали за різницею вологої та висушеної до постійної ваги у сушильній шафі кістки при температурі $105^{\circ} \mathrm{C}$. Потім висушені кістки спалювали у муфельній печі при температурі $450{ }^{\circ} \mathrm{C}$. Вага попелу слугувала показником загальної кількості мінеральних речовин у кістці. На спектрофотометрі СФ-115 (метод Б. А. Семенко, М. М. Молдакулова (1980)) визначали кількісний вміст кальцію, калію, натрію, магнію, міді, марганцю, цинку, заліза та свинцю. Кількість фосфору 
Огляди літератури, оригінальні дослідження, погляд на проблему

визначали за Брігом на фотоелектрокалориметрі. Одержаний в результаті експерименту цифровий матеріал статистично обробляли з використанням критерію Стьюдента на персональному комп'ютері за допомогою програми Microsoft Excel (USA). Достовірною вважали ймовірність помилки менше $5 \%(p<0,05)$.

Результати й обговорення. Вміст води у кістках тварин молодого віку після помірних фізичних навантажень динамічного характеру протягом 20, 40, 60 днів експерименту збільшується на $(18,40 \pm 0,48)$ $(0,13 \%) ;(18,67 \pm 0,60)$ (1,47\%); $(19,08 \pm 0,49)(2,16 \%)$ відповідно. У тварин цієї ж вікової групи, які отримували інтенсивні фізичні навантаження, вміст води у кістках значно зменшується - на $(18,10 \pm 0,62)(1,52 \%)$; $(17,25 \pm 0,56)(4,69 \%) ;(16,38 \pm 0,44)(5,08 \%)$, відповідно (рис. 1). Аналогічно змінюються показники вмісту води у плечових кістках тварин зрілого віку, які отримували помірні та інтенсивні фізичні навантаження динамічного характеру протягом 20, 40, 60 днів експерименту (рис. 1).

Кістки тварин старечого віку реагують на помірні фізичні навантаження збільшенням кількості води, що становить $(29,99 \pm 1,73)(021 \%) ;(30,01 \pm 0,63)$ $(0,36 \%) ;(30,39 \pm 1,41)(0,14 \%)$. У тварин цього ж віку, які отримували інтенсивні фізичні навантаження, вміст води протягом 20, 40 днів експерименту значно зменшується - на $(22,01 \pm 0,29)$ (5,38 \%); $(20,63 \pm 0,36)(7,14 \%)$; через 60 днів цей показник збільшується на $(18,81 \pm 0,28)(3,13 \%)$ (рис. 1$)$.

Значно зростає кількість мінеральних речовин у тварин молодого віку, які протягом 20, 40, 60 днів отримували помірні фізичні навантаження (рис. 2), у тварин цього ж віку, які отримували інтенсивні навантаження, їх вміст зменшується на
$(57,67 \pm 1,55) \quad(2,30 \%) ; \quad(62,51 \pm 2,71) \quad(4,69 \%)$; $(70,27 \pm 1,80)(5,08 \%)$, відповідно.

У тварин зрілого віку після помірних фізичних навантажень протягом 20, 40, 60 днів загальна кількість мінеральних речовин збільшується на $(74,69 \pm 1,98)(4,82 \%) ;(74,70 \pm 1,96)(3,97 \%)$; $(78,91 \pm 2,12)(5,61 \%)$ відповідно, а після інтенсивних навантажень їх кількість зменшується на $(45,63 \pm 1,02) \quad(1,76 \%) ; \quad(44,83 \pm 0,95) \quad(5,32 \%)$; $(44,09 \pm 1,35)(9,43 \%)$ відповідно (рис. 2).

Даний показник збільшується у старечих тварин, які отримували протягом двох місяців експерименту помірні фізичні динамічні навантаження, на $(79,16 \pm 1,92)(0,94 \%) ;(79,27 \pm 1,93)(1,58 \%)$; $(83,46 \pm 1,26)(1,77$ \%). У тварин цього ж віку, які отримували інтенсивні фізичні навантаження, загальна кількість мінеральних речовин значно зменшується, відповідно на $(63,72 \pm 1,17)(0,73 \%)$; $(53,32 \pm 1,20)(2,61 \%) ;(49,57 \pm 1,11)(8,99 \%)$ (рис. 2$)$.

Тварини молодого віку, які протягом 20, 40, 60 днів експерименту отримували помірні фізичні навантаження, реагують збільшенням кількості кальцію у плечовій кістці (рис. 3), тоді як інтенсивні навантаження за весь час експерименту призводили до зменшення кількості кальцію на $(23,05 \pm 1,56) \quad(2,64 \%) ; \quad(21,76 \pm 0,53) \quad(5,60 \%)$; $(19,96 \pm 0,48)(8,26 \%)$, що може бути причиною остеопоротичних проявів.

Протягом усього експерименту значно збільшується вміст кальцію у тварин зрілого віку, які отримували помірні фізичні навантаження (рис. 3). У тварин цього ж віку інтенсивні навантаження протягом 20 днів призводять до збільшення вмісту кальцію лише на $(18,32 \pm 0,40)(2,62 \%)$, тоді як через 40 і 60 днів спостерігається значне

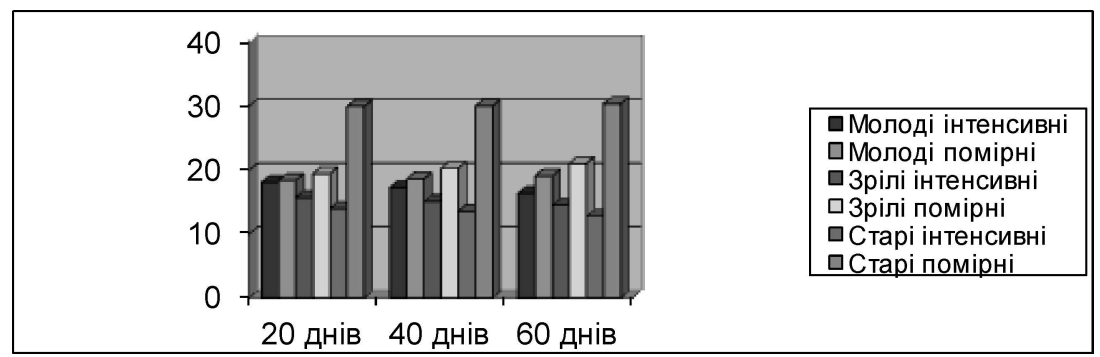

Рис. 1. Відсоткове співвідношення води у плечовій кістці тварин при інтенсивних та помірних фізичних навантаженнях.

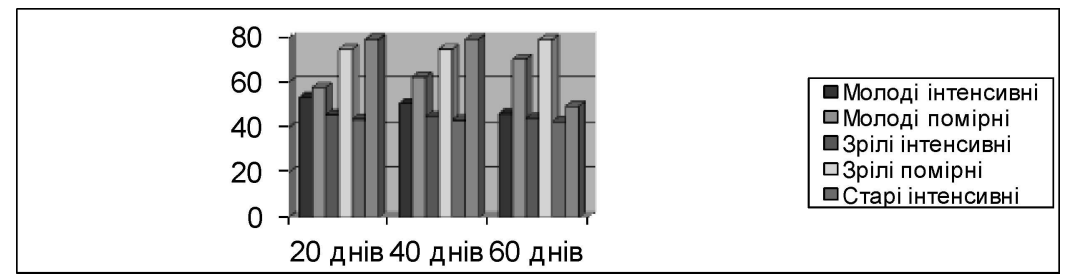

Рис. 2. Відсоткове співвідношення мінеральних речовин (на суху речовину) у плечовій кістці тварин при інтенсивних та помірних фізичних навантаженнях. 


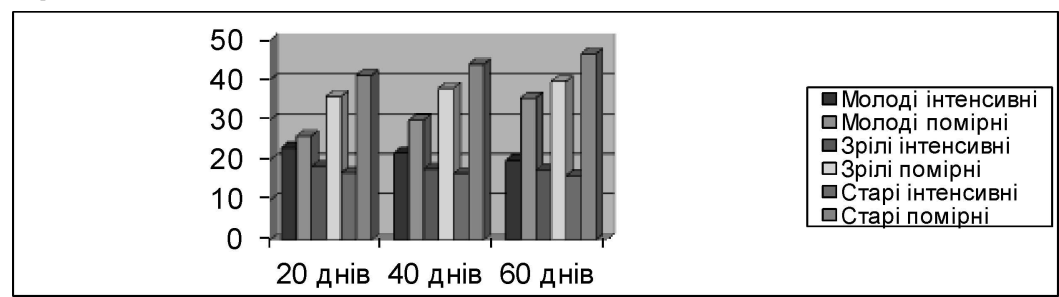

Рис. 3. Відсоткове співвідношення кальцію у плечовій кістці тварин при інтенсивних та помірних фізичних навантаженнях.

зменшення вмісту кальцію - на $(17,79 \pm 0,47)$ $(1,95 \%) ;(17,49 \pm 0,45)(6,31 \%)$.

У тварин старечого віку після помірних фізичних навантажень протягом (20, 40, 60 днів) експерименту кількість кальцію збільшується, відповідно, на $(41,08 \pm 1,00)(1,23 \%) ;(43,81 \pm 1,12)$ $(5,17 \%) ;(46,46 \pm 1,01)(7,63 \%)$. Після інтенсивних навантажень цей показник значно зменшується на $(36,77 \pm 0,35)(2,02 \%) ;(31,71 \pm 0,45)(4,67 \%)$; $(30,04 \pm 0,42)(3,24 \%)$ (рис. 3$)$.

Плечові кістки тварин молодого віку реагують на двомісячні помірні фізичні навантаження значним збільшенням вмісту фосфору (рис. 4). У тварин цього ж віку, які отримували інтенсивні фізичні навантаження, вміст фосфору значно змен- шується - на $(12,04 \pm 0,29)(1,95 \%) ;(11,31 \pm 0,24)$ $(6,07 \%)$; $(10,48 \pm 0,27)(7,34 \%)$, відповідно, протягом 20, 40, 60 днів експерименту.

Аналогічні дані ми спостерігаємо у тварин зрілого віку, які отримували помірні та інтенсивні фізичні навантаження динамічного характеру протягом двомісячного експерименту (рис. 4).

Спостерігаємо збільшення фосфору у кістках старечих тварин, які протягом 20, 40, 60 днів експерименту отримували помірні навантаження на $(21,36 \pm 0,64) \quad(0,56 \%) ; \quad(22,42 \pm 0,57) \quad(4,43 \%)$; $(24,85 \pm 0,43)(8,31 \%)$. Значне зменшення вмісту фосфору спостерігається у плечових кістках тварин старечого віку, які отримували інтенсивні фізичні навантаження (рис. 4).

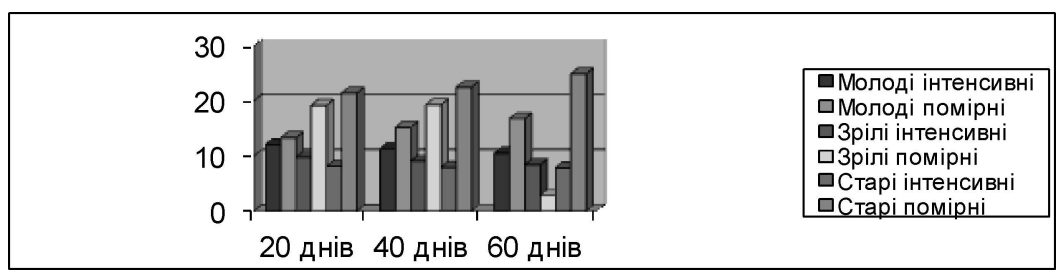

Рис. 4. Відсоткове співвідношення фосфору у плечовій кістці тварин при інтенсивних та помірних фізичних навантаженнях.

Висновки. Застосування єдиного методичного підходу і комплексу адекватних методів дослідження на великому однорідному експериментальному матеріалі дозволило встановити закономірності морфофункціональних перетворень структури довгих кісток тварин, що відбуваються в умовах різних режимів рухової активності в різних вікових групах.

Інтенсивні фізичні навантаження викликають сповільнення росту та остеокластичну резорбцію плечових кісток і їх структурних елементів у тварин молодого та зрілого віку. У тварин з вираженими старечими змінами спостерігаються значні деструктивні зрушення в усіх відділах плечових кісток. Морфометричні методи дослідження дозволяють стверджувати про максимальні руйнівні зміни кісток у групі старих тварин і мінімальні - у тварин зрілого віку. Помірні фізичні навантаження $є$ фактором стримування інволютивних змін у плечових кістках. У групі молодих тварин спостерігаєть сповільнення процесів звуження ширини росткової пластинки та збільшення активності остеобластів, що опосередковано проявлялося збільшенням розмірів кісток та їх структури в експериментальних тварин. У групі тварин з вираженими старечими змінами помітне сповільнення де-мінералізації кістки. Встановлено, що ефект дії різних режимів рухової активності на процеси морфогенезу залежить від віку, а також від інтенсивності і тривалості фізичних навантажень. Результати проведеного дослідження мають як теоретичне, так і практичне значення, оскільки дають методичну базу для вивчення адаптаційних перетворень у кістковій системі, визначення діапазону її перетворень. Експериментально підтвердженна можливість прогнозування тренувальних вправ та цілесплямованого використання дозованих фізичних навантажень 3 метою корекції структурних змін скелета залежно від віку.

Перспективи подальших досліджень. Отримані дані про зміни кісткової тканини при застосуванні інтенсивних навантажень $€$ теоретичним під- 
Огляди літератури, оригінальні дослідження, погляд на проблему

ґрунтям для розробки та профілактики захворювань опорно-рухового апарату, остеопорозу, різних стадій сколіозів, вертеброгенної патології у тренувальному процесі, спорті. Виявлені закономірності морфофункціональних перетворень за дії на організм різних режимів рухової активності дають можливість обґрунтувати комплекс заходів для корегування змін у кістковій системі людей, котрі припинили активні заняття спортом або фізичною працею.

\section{ЛIТЕРАТУРА}

1. Аксенова Н. Повышение уровня двигательной активности и дозировка физической загрузки на физкультурных занятиях / Н. Аксенова // Дошкольное воспитание. - 2000. - № 6. - С. $37-48$.

2. Каваре В. І. Морфометрія епіфізарного хряща довгих кісток тварин в умовах екологічного забруднення / В. І. Каваре, М. Х. Абакаров, В. І. Лузін // Таврический медико-биологический вестник. - 2004. - Т. 7, № 4. - С. $171-172$

3. Ковешников В. Г. Алгоритм остеометрического исследования / В. Г. Ковешников, В. В. Маврич, С. А. Кащенко // Буковинський медичний альманах. - 2003. T. 7, № 3. - С. 180-186.

4. Линець М. М. Основні методики розвитку рухової якості : навч. посіб. для фізкультурних вузів. - Л. : Штабар, 1997. - 100 с.
5. Лоза Т. О. Рухова активність як невід'ємний компонент здорового способу життя // Формування здоров'я дітей, підлітків та молоді в умовах навчальновиховного закладу: матеріали Всеукраїнської науковопрактичної конференції. - Суми : СумДПУ ім. А. С. Макаренка, 2006. - С. 210-212.

6. Попов В. В. Вариабельность сердечного ритма: возможности применения в физиологии и клинической медицине / В. В. Попов, Л. Н. Фритше //Український медичний часопис. - 2006. - № 2 (52). - С. 24-31.

7. Формування навичок здорового способу життя молоді / Упоряд. А. Флойбман. - К. : ТОВ Видавництво «Шкільний світ», 2002. - 111 с.

8. Multivariate and multiorgan analysis of cardiorespiratory variability signals: the CAP sleep case / A. M. Bianchi, L. Ferini-Strambi, V. Castranovo, S. Cerutti // Diomed. Tech (Berl). - 2006. - № 51 (4). - P. 167-173.

\title{
RESTRUCTURING OF CHEMICAL COMPOSITION OF BONE IN AGE ASPECT ACCORDING TO VARIOUS MODES OF PHYSICAL ACTIVITY
}

\author{
ON. O. Davybida, N. M. Bezpalova, L. V. Novakova, A. V. Rutska \\ I. Horbachevsky Ternopil State Medical University
}

SUMMARY. A deep study of the adjustment processes of bone, its structure, chemical composition, adaptive capacity is a necessary condition for clarification of the influence of labor, sports and a number of trades that occur in connection with the scientific and technical progress on the body. Simulation of the different modes of motor activity does not fully meet the training process rights in physical education and sport. However, the results obtained in this pilot study are related to the disclosure of general biological laws based on individual and genetically determined characteristics of individuals, knowledge of which will serve as a morphological substantiation of the training process and prediction of structural changes in the skeleton at various modes of physical activity, injury prevention, and the development of osteoporosis.

KEY WORDS: exercise, endurance, macro-micro elements, humerus. 